\title{
Common Financial Data And Tax And Accounting Strategies In Spanish Micro- Enterprises
}

Guillermo Ceballos-Santamaría, University of Castilla-La Mancha, Spain Juan-José Villanueva-Álvaro, University of Castilla-La Mancha, Spain

\begin{abstract}
In EU governments, there is widespread concern of the current trends in small businesses. Their importance in generating wealth and employment justifies the adoption of economic measures to foster their development and durability. Experience shows that few European micro-enterprises are handed on to a second generation of owners and almost none to a third.
\end{abstract}

Moreover, in times of crisis, the notion that micro-enterprises (including self-employed or businesspeople with no employees) should become the first link in economic recovery and employment generation appears recurrently.

This paper studies the distinguishing features of such companies in a Spanish province through a descriptive statistical analysis of the basic data and ratios in their accounting statements.

Keywords: Micro-Enterprise; Tax And Accounting Strategy; Balance Sheet Structure

\section{INTRODUCTION}

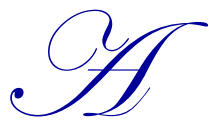

ccording to data on 1 January, 2013, from the Central Companies Directory (DIRCE) at the National Statistical Institute (INE), 53.4\% of Spanish companies have no employees. The percentage of companies with two employees or less is as high as $82.7 \%$. The Europe-wide figures are also significant. According to limits set in 2005, the EU defines a small Enterprise, in staffing terms, as any firm employing less than 50 workers and a micro-enterprise as one with less than ten workers. With these parameters, 92\% of European firms are regarded as micro-enterprises (European Communities, 2003; 2006). Likewise, selfemployment is growing, along with the attention given to it by public administration (Cueto, 2006, García and Martínez, 2003). The limits established by the EU are determined by three criteria - turnover, balance sheet total, and staff headcount (Arrondo, 2002).

These variables are used to differentiate between medium-sized firms, small firms and micro-enterprises. A medium-sized firm is defined as an enterprise employing fewer than 250 persons and with an annual turnover of no more than 50 million Euros, and/or whose balance sheet does not total more than 43 million Euros. A small firm employs 50 persons, its turnover is less than 10 million Euros, and/or it has a balance sheet totaling less than 10 million Euros (Melle, 2001). The category of micro-enterprise or micro-SME covers firms with less than 10 employees and with an annual turnover or assets not exceeding two million Euros. One of the most notable criticisms received by this new system (Morillas, 2002) questions the employee headcount based on the number of annual work units (AWU).

Yet whether or not the criteria are fit for purpose, the micro-enterprise concept is recognizable in all Member States, and although in each country they have distinguishing features, there are common characteristics across Europe in this type of company. All have vital importance in the business fabric of their respective countries. For them to survive, their managers (almost always the owners of the firm) have to strive to continually adapt to the 
environment in which their business operates (Ceballos, 2009; Ceballos et. al., 2012). Finally these firms are often hard to study, as it is difficult to procure reliable financial data on them (especially with regard to the smallest companies).

\section{METHODOLOGY AND OBJECTIVES}

The Official Journal of the European Communities (OJEC 2003) specifies the staff head counts and financial thresholds defining the various company categories as follows: “(...) a micro-enterprise is defined as an enterprise which employs fewer than 10 persons and whose annual turnover and/or annual balance sheet total does not exceed EUR 2 million."

All Member States, as well as the European Investment Bank and European Investment Fund, which previously used a wide range of non-homogenous criteria for defining SMEs, were to replace the old criteria with the new ones and to adapt the statistics that they prepare in accordance with these categories.

For the sample frame, the authors used information provided by the SABI (Sistemas de Análisis de Balances Ibérico) database of the company Informa, S.A. It contains general information and financial data on Spanish and Portuguese companies and provides details of the accounting statements of firms more than one year old with at least one set of annual accounts registered with the Register of Companies. The authors first decided upon a geographic sampling territory, selecting the province of Cuenca. Of all the firms in that database, 3,741 are located in Cuenca province.

After defining that province as the analytical territory, the authors selected only companies with accounting information available for 2006, thereby limiting the size of the sample. They then set search criteria relating to company size, applying the definition of micro-enterprise proposed by the Official Journal of the European Communities, with a final sample of 1,354 companies.

\section{EMPIRICAL FINDINGS}

Having obtained the study sample consisting of 1,354 micro-enterprises in the province of Cuenca (Spain), the authors studied the balance sheet and profit and loss account items liable to provide most financial information for their study.

The account items taken and the ratios obtained from them were the following: Income, Profit on the year, Assets, Net equity, Economic rate of return, Financial rate of return, Level of debt, Number of employees, Growth in sales, Asset rotation, Productivity and Growth in added value. On the basis of the above indicators, the authors obtained the results that they set out below, with an analysis of those that they regard as most representative (Instituto Nacional de Estadística, 2013).

Starting with income, given the importance of this item for a company, the authors found an average value of some $€ 350,000$ a year. This figure, together with data on its asymmetry - with a high rate and skewed to the right - shows a low level of sales in micro-enterprises in Cuenca province. In applying a 75\% percentile, they find that just a quarter of companies turn over more than 430,000 euros. The data show a population of companies who individually have small market shares. This is a paradigmatic characteristic of the service sector in which principle firms need no great investment in assets or capital contribution to start operating. 
Table 1: Descriptive Statistics

\begin{tabular}{|c|c|c|c|c|c|c|c|c|}
\hline & & Ingresos & Resultado & Activo & FPropios & Renteco & Rentfin & Liquidez \\
\hline \multirow[t]{2}{*}{ N } & Válidos & 1354 & 1354 & 1354 & 1354 & 1351 & 1336 & 1339 \\
\hline & Perdidos & 0 & 0 & 0 & 0 & 3 & 18 & 15 \\
\hline \multicolumn{2}{|l|}{ Media } & 349057,3 & 2336,9764 & 282644,3 & 59287,99 & $-1,9117$ & 14,3494 & 2,3191 \\
\hline \multicolumn{2}{|l|}{ Mediana } & 231724,0 & 2332,5000 & 181620,0 & 25692,50 & 1,2000 & 9,4750 & 1,0200 \\
\hline \multicolumn{2}{|l|}{ Moda } & $75140,00^{\mathrm{a}}$ & $-16075,00^{a}$ & $16455,00^{\mathrm{a}}$ & $3422,00^{\mathrm{a}}$ & ,34 & 1,90 & 1,02 \\
\hline \multicolumn{2}{|l|}{ Desv. típ. } & 357889,5 & 32102,15 & 290675,5 & 132454,1 & 34,58350 & 105,06959 & 10,84018 \\
\hline \multicolumn{2}{|l|}{ Varianza } & $1 \mathrm{E}+011$ & $1,0 \mathrm{E}+009$ & $8 \mathrm{E}+010$ & $2 \mathrm{E}+010$ & 1196,019 & 11039,618 & 117,509 \\
\hline \multicolumn{2}{|l|}{ Asimetría } & 2,076 & $-2,054$ & 2,062 & 3,714 & $-7,042$ & ,412 & 21,526 \\
\hline \multicolumn{2}{|c|}{ Error típ. de asimetría } &, 066 &, 066 &, 066 &, 066 &, 067 &, 067 & ,067 \\
\hline \multicolumn{2}{|l|}{ Curtosis } & 4,538 & 34,332 & 5,021 & 28,736 & 121,173 & 31,460 & 558,431 \\
\hline \multicolumn{2}{|c|}{ Error típ. de curtosis } &, 133 & ,133 &, 133 & , 133 & ,133 & , 134 & , 134 \\
\hline \multirow[t]{3}{*}{ Percentiles } & 25 & 114608,3 & $-3142,000$ & 87652,00 & 4952,2500 &,- 3100 & 1,9300 & ,6700 \\
\hline & 50 & 231724,0 & 2332,5000 & 181620,0 & 25692,50 & 1,2000 & 9,4750 & 1,0200 \\
\hline & 75 & 432459,5 & 9666,2500 & 373358,0 & 73871,75 & 4,1500 & 23,8275 & 1,4800 \\
\hline
\end{tabular}

a. Existen varias modas. Se mostrará el menor de los v alores.

The average profit figure is 2,337 euros, with a very high kurtosis and asymmetry skewed to the left. In a graphic representation, the peakedness would centre on values near zero (no profit).

Table 2: Descriptive Statistics

\begin{tabular}{|c|c|c|c|c|c|c|c|c|}
\hline & & Endeuda & Empleados & CreVentas & Ractivos & Product & CreVA & GasFinan \\
\hline \multirow[t]{2}{*}{$\bar{N}$} & Válidos & 1349 & 1354 & 1238 & 1334 & 1353 & 1193 & 1186 \\
\hline & Perdidos & 5 & 0 & 116 & 20 & 1 & 161 & 168 \\
\hline \multicolumn{2}{|l|}{ Media } & 84,1473 & 3,6846 & 26,8427 & 1,9625 & 1,5692 & 26,7246 & 3,5327 \\
\hline \multicolumn{2}{|l|}{ Mediana } & 83,4600 & 3,0000 & 7,8500 & 1,3500 & 1,2400 & 8,0300 & ,8100 \\
\hline \multicolumn{2}{|l|}{ Moda } &, 00 & 2,00 & $-3,53^{a}$ &, 75 & 1,10 &, $11^{\mathrm{a}}$ &, 00 \\
\hline \multicolumn{2}{|l|}{ Desv. típ. } & 52,28113 & 2,14348 & 94,48913 & 3,15260 & 7,03140 & 99,94507 & 30,60291 \\
\hline \multicolumn{2}{|l|}{ Varianza } & 2733,316 & 4,594 & 8928,197 & 9,939 & 49,441 & 9989,018 & 936,538 \\
\hline \multicolumn{2}{|l|}{ Asimetría } & 5,349 & 661 & 4,928 & 12,767 & 34,232 & 5,188 & 23,967 \\
\hline \multicolumn{2}{|c|}{ Error típ. de asimetría } & ,067 & ,066 &, 070 &, 067 & ,067 & 071 & 071 \\
\hline \multicolumn{2}{|l|}{ Curtosis } & 48,333 &,- 393 & 31,580 & 248,299 & 1226,405 & 36,270 & 641,944 \\
\hline \multicolumn{2}{|c|}{ Error típ. de curtosis } & ,133 & ,133 & 139 & ,134 & 133 & ,142 & ,142 \\
\hline \multirow[t]{3}{*}{ Percentiles } & 25 & 63,8450 & 2,0000 & $-7,2050$ & ,7700 & 1,0600 & $-9,2800$ & ,2600 \\
\hline & 50 & 83,4600 & 3,0000 & 7,8500 & 1,3500 & 1,2400 & 8,0300 & ,8100 \\
\hline & 75 & 96,1750 & 5,0000 & 30,4750 & 2,2600 & 1,5700 & 30,7100 & 2,1300 \\
\hline
\end{tabular}

a. Existen varias modas. Se mostrará el menor de los valores.

A comparison of profit and equity across all the companies is also significant. The quantity obtained is abnormally low. In this respect, it is worth noting that most of the firms studied had the legal status of limited companies (95\%), with the legal minimum of capital of 3,005.06 euros. This is the capital with which such companies are normally set up. If the authors compare these capital figures with total equity, they find that they form a very small portion or, in other words, the greater part of company equity consists of reserves (undistributed profit). 
Table 3: Descriptive Statistics

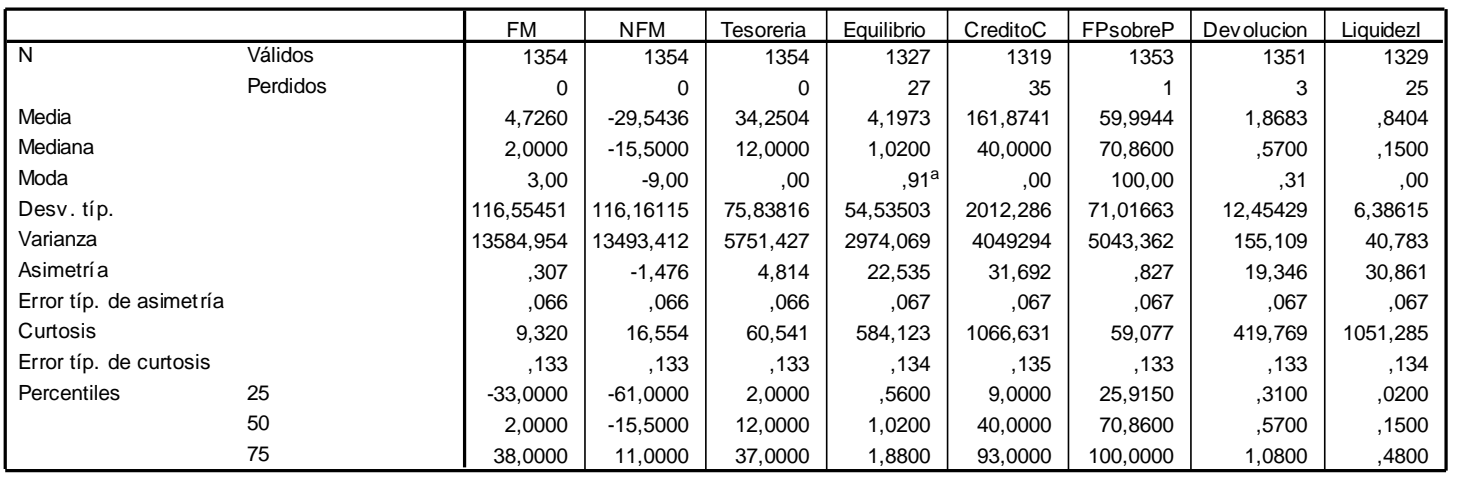

a. Existen varias modas. Se mostrará el menor de los valores.

In analysing the level of debt, the authors find very high figures in absolute terms, but they believe that the actual data may be better than in the results obtained given that the data used in the sample may be unreliable due to a lack of unbundling. This limitation arises because all the companies studied submit their accounts to the Register of Companies (from which submission the sample data are obtained) as an abridged balance sheet, which distinguishes only between short-term and long-term debts, with no further breakdown. So, it may be that these allinclusive items include debts that companies have with their own members or shareholders.

Table 4: Micro-Enterprise Employees

\begin{tabular}{|rr|r|r|r|r|}
\hline & Frecuencia & Porcentaje & $\begin{array}{c}\text { Porcentaje } \\
\text { válido }\end{array}$ & $\begin{array}{c}\text { Porcentaje } \\
\text { acumulado }\end{array}$ \\
\hline Válidos & 1,00 & 220 & 16,2 & 16,2 & 16,2 \\
& 2,00 & 260 & 19,2 & 19,2 & 35,5 \\
3,00 & 254 & 18,8 & 18,8 & 54,2 \\
4,00 & 192 & 14,2 & 14,2 & 68,4 \\
5,00 & 145 & 10,7 & 10,7 & 79,1 \\
6,00 & 109 & 8,1 & 8,1 & 87,1 \\
7,00 & 90 & 6,6 & 6,6 & 93,8 \\
8,00 & 46 & 3,4 & 3,4 & 97,2 \\
9,00 & 38 & 2,8 & 2,8 & 100,0 \\
Total & 1354 & 100,0 & 100,0 & \\
\hline
\end{tabular}

Finally, the descriptive statistics on staff clearly show that we are dealing with very small companies (micro-enterprises). The mean head count is 4.6 employees per company. If a $25 \%$ percentile is applied, the figure shows just two employees, only one quarter of companies have more than five employees in their workforce, and just 38 of the 1,354 firms studied have the maximum number of nine workers.

\section{CONCLUSIONS}

From this study, the authors may draw the following conclusions on small companies.

The profits of such firms are, in most cases, too low. Just $25 \%$ of the companies make a profit of more than 10,000 Euros. The average figure for profits represents just $0.67 \%$ of sales.

To account for this situation, the authors should keep in mind that on most occasions in such companies, the shareholder (owner) is normally also a paid employee as he/she works in the company. Moreover, if this shareholder-worker holds more than 33\% of the firm's capital (which is quite common), he/she has to make social security contributions as a self-employed worker. This means that the shareholder may raise or lower his/her salary at will without having to contribute more, for contributions and wage levels are independent, which is not the case for employees covered by the general social security system. Thus, by raising or lowering their salary, they can 
adjust the tax they have to pay. If they raise it, the company has more expenses, which reduces profit and therefore means that less corporation tax is payable.

So, the authors may be finding deceptive (excessively low) levels of profit due more to tax strategy than to the reality of a company's activity. The lack of correlation between the income and profit variables gives weight to this thesis.

Moreover, the authors find that micro-enterprises do not distribute dividends (in this simple, dividends were distributed by less than $1 \%$ of companies). Again the reason is likely to be to save on tax - if companies distribute dividends, the company shareholder is taxed twofold, with income tax on capital income, in addition to the corporation tax paid earlier. This means that dividends are not distributed and shareholders prefer to take funds from the company by other means, such as by taking out a loan, legally or de facto, or simply by keeping a current account with the firm.

From the results obtained, the authors may assume that the profits reported on the accounting statements of micro-enterprises reflect tax and accounting strategy rather than the reality, calling into question the accounting principle of giving a true and fair view.

\section{AUTHOR INFORMATION}

Guillermo Ceballos-Santamaria is an Assistant Professor in the Economics Department, Faculty of Social Sciences of Cuenca, at the University of Castilla-La Mancha (Spain) and has a Degree in Business Administration from the University of Valencia as well as a Degree in Advanced Studies in Economic from the University of Castilla-La Mancha. Research interests include economics and tourism. E-mail: Guillermo.Ceballos@uclm.es.

Juan-José Villanueva-Álvaro is an Assistant Professor in the Economics Department, Faculty of Social Sciences of Cuenca, at the University of Castilla-La Mancha (Spain) and has a Degree in Business Administration from the University of Valencia. Research interests include economics and tourism. E-mail: JuanJose.Villanueva@uclm.es.

\section{REFERENCES}

1. Arrondo, R. (2002): "La valoración por el mercado de capitales español de la decisión de ampliar capital: efectos informativos y costes de agencia". Revista europea de dirección y economía de la empresa, vol. 11, $\mathrm{n}^{\mathrm{o}} 3$, pp. 35-46.

2. Ceballos, G. (2009): Caracterización de la micropyme en Cuenca:Un análisis a través de los estados contables. Universidad de Castilla La Mancha. Cuenca.

3. Ceballos, G.; Villanueva, J. J. and Mondéjar, J. (2012): Micro-SME Characterization From Financial Statements. International Business \& Economics Research Journal. 11(13), pp. 1507-1512.

4. Cueto, B. (2006): "Autoempleo, autónomos y economía social en España". Perspectivas del Sistema Financiero, 86, pp. 35-47.

5. European Communities. (2006): SMEs and entrepreneurship in the EU, Statistics in focus, 24/2006.

6. García, P. and Martínez, P. (2003): "La tesorería en la empresa y sus determinantes". Documento de Trabajo WP-EC 2003-19, Facultad de economía y empresa. Universidad de Murcia.

7. Instituto Nacional de Estadística. (2013): Directorio Central de Empresas DIRCE. Aviable in: www.ine.es.

8. Melle, M. (2001): “Características diferenciales de la financiación entre las pymes y las grandes empresas españolas". Papeles de Economía Española, 89-90, pp. 140-159.

9. Morillas, J. (2002): "Hacia una definición de la pyme en la Unión Europea. Justificación y crítica".Boletín económico de ICE, 2721, pp.25-29.

10. Official Journal of the European Communities (OJEC). (2003). de 20 de mayo $\mathrm{n}^{\circ} \mathrm{L}$ 124/36-41. Recomendación 2003/361/CE de la Comisión de 6 de mayo de 2003 sobre la definición de microempresas, pequeñas y medianas empresas. 
NOTES 